\title{
Properties of Two Inhibitors of Plant Virus Infection from Fruiting Bodies of Lentinus edodes and from Leaves of Yucca recurvifolia Salisb. ${ }^{\dagger}$
}

\author{
Akira Hiramatsu, Norifumi Kobayashi and Naofumi Osawa \\ Laboratory of Agricultural Chemicals, Faculty of Agriculture, Ibaraki University, \\ Ami-machi, Inashiki-gun, Ibaraki 300-03, Japan
}

Received October 6, 1986

\begin{abstract}
One of the inhibitors, named "fruiting body protein (FBP)," was purified from fruiting bodies of Lentinus edodes, and the other, named "yucca leaf protein (YLP)," from leaves of Yucca recurvifolia Salisb. The properties of these inhibitors were investigated, and the concentration of substances for a $50 \%$ inhibition ratio of TMV infection were measured. The inhibition ratios of YLP, FBP, Poly-Lys, Poly-Orn, Poly-Arg and cytochrome $c$ were 0.6, 6.3, 14.1, 31.6, 44.7 and $100 \mathrm{ppm}$, respectively. Two inhibitors had no RNA hydrolyzing activity and no activity to TMV aggregation. FBP and YLP prevented infection of the plant by TMV when treated within 3 days before TMV inoculation, but not when treated within $1 \mathrm{hr}$ for FBP or $3 \mathrm{hr}$ for YLP after TMV inoculation. It seems that these two inhibitors had a preventive effect on plant virus infection, but no curative effect.
\end{abstract}

In a previous series of studies, ${ }^{1,2)}$ two substances having inhibitory activity to plant virus infection were purified and named "fruiting body protein (FBP)" and "yucca leaf protein (YLP)." These two inhibitors were purified from fruiting bodies of Lentinus edodes or from leaves of Yucca recurvifolia Salisb. The molecular weight of the two inhibitors was 23,000 , and they were simple proteins possessing no carbohydrate. The amino acid residues per mol of FBP and YLP were estimated to be about 199 and 208, respectively.

Inhibitors of plant infection, which were described in Table III of a previous paper, ${ }^{1)}$ were a basic proteins, and have been reported by many investigators. Stirpe et ll $^{3)}$ reported Dianthin 30 and 32 purified from leaves of Dianthus caryophyllus and containing a small amount of saccharide. Irvin and co-workers reported PAP, ${ }^{4)}$ PAP II $^{5)}$ and PAP $\mathrm{S}^{6)}$ purified from leaves or seeds of Phytolacca americana. These inhibitors were also reported to be basic proteins and to have the ability to inhibit protein synthesis. Also, Lentemin, which was polysaccharide and purified from a culture cell of Lentinus edodes, was reported by Maeda, ${ }^{7)}$ and KR-070, which was glycoprotein and purified from a culture cell of Aspergillus oryzae, was reported by Ikeda. ${ }^{8)}$

Kubo et al. ${ }^{9)}$ have reported that the substance purified from roots of Mirabilis jalapa L., using chromatography on a CM-Sepharose CL-6B column, strongly inhibited TMV infection. This substance was basic protein and its molecular weight was 24,200 .

In this paper we report several properties of FBP and YLP.

$\dagger$ An Inhibitor of Plant Virus Infection. Part III. This work was presented at the Annual Meeting of the Pesticide Science Society of Japan in Shizuoka, 1984, and in Tokyo, 1985.

Abbreviations: FBP, fruiting body protein; YLP, yucca leaf protein; TMV, tobacco mosaic virus; RNA, ribonucleic acid; Poly-Lys, poly-L-lysine; Poly-Orn, poly-L-ornithine; Poly-Arg, poly-L-arginine; Poly-Leu, poly-L-leucine; Poly-Ala, poly-L-alanine; Poly-Glu, Poly-L-glutamic acid; Arg, L-arginine; Lys, L-lysine; Orn, L-ornithine; RNase, ribonuclease A; TMV-RNA, ribonucleic acid of tobacco mosaic virus. 


\section{MATERIALS AND METHODS}

Materials. Poly-L-lysine (Poly-Lys I, average molecular weight MW =60,000; Poly-Lys II, MW =40,000; Poly-Lys III, MW =25,000; and Poly-Lys IV, MW =11,000), polyL-ornithine (Poly-Orn I, MW $=110,000$; Poly-Orn II, $\mathrm{MW}=30,000 ; \quad$ Poly-Orn III, $\mathrm{MW}=10,000)$, poly-Larginine (Poly-Arg, MW=130,000), poly-L-leucine (PolyLeu, $\mathrm{MW}=17,000$ ), poly-L-alanine (Poly-Ala, $\mathrm{MW}=$ 23,000 ), ribonuclease A (bovine pancreas), $\alpha$-lactoalbumin (bovine milk, approx. 85\%) and ribonucleic acid (bakers yeast) were purchased from Sigma Co. Poly-L-glutamic acid (Poly-Glu, MW unknown), L-lysine (Lys), L-ornithine (Orn) and L-arginine (Arg) were obtained from the Peptide Institute of the Protein Research Foundation. Cytochrome $c$ (horse heart, crystallized) was kindly supplied from Nikken Kagaku Co., $\alpha$-casein was purchased from E. Merck A G., and Toyopearl HW60F from Toyo Soda Mfg. Co., Ltd.

Preparation of virus inhibitors. FBP purified from fruiting bodies of $L$. edodes and YLP from leaves of $Y$. recurvifolia were prepared by the methods previously described. ${ }^{1,2)}$ The homogeneity of these inhibitors was confirmed by SDS disc electrophoresis.

Virus. Tobacco mosaic virus-ordinary strain (TMV) was multiplied in tobacco plants (Nicotiana tabacum L. var. xanthi). TMV was purified according to the method of Fukuchi et al. ${ }^{10)}$ and stored at $-20^{\circ} \mathrm{C}$ until used.

Preparation of TMV-ribonucleic acid. TMV-ribonucleic acid (TMV-RNA) was prepared according to the method of Fraenkel-Conrat et al. ${ }^{11)}$ using phenol and bentonite.

Test plants. Chenopodium amaranticolor L. was grown in a greenhouse and used as a local lesion host for TMV.

Assay for inhibitory activity to plant virus infection. The inhibitory activity to plant virus infection using TMV or TMV-RNA was assayed according to the method of Gianinazzi and Kassanis ${ }^{12)}$ as previously described. ${ }^{1)}$

The relative inhibition ratio $(\%)$ of the inhibitor was calculated according to the following equation:

Inhibition ratio $(\%)$

$$
=\left(1-\frac{\text { number of lesions by the sample }}{\text { number of lesions by the control }}\right) \times 100
$$

When the inhibitor solution was applied before TMV inoculation, the leaves of the test plant were rubbed with a gum sponge containing the inhibitor or buffer (as a control) solution. The treated leaves were then washed thoroughly with deionized water immediately. When the inhibitor or buffer solution was applied after TMV inoculation, the leaves of the test plant were not washed after the treatment.

Assay for protein concentration. The protein concentration of the inhibitor was measured by the method Lowry et al. ${ }^{13)}$ as previously described. ${ }^{1)}$

Assay of ribonucleic acid ( $R N A)$ hydrolyzing activity. The reaction mixture $(1.0 \mathrm{ml})$ for the assay of RNA hydrolyzing activity contained $3.0 \mathrm{mg}$ of yeast RNA, $2 \mu \mathrm{mol}$ of EDTA, $25 \mu \mathrm{mol}$ of acetate buffer ( $\mathrm{pH} \mathrm{5.2)}$ ), and FBP $(100 \mu \mathrm{g})$, YLP $(100 \mu \mathrm{g})$ or ribonuclease A $(20 \mu \mathrm{g})$ as a sample. After incubating at $37^{\circ} \mathrm{C}$ for various times, the reaction was terminated by adding $0.25 \mathrm{ml}$ of $0.75 \%$ uranyl acetate containing $25 \%$ perchloric acid. The mixture was centrifuged at $3,000 \mathrm{rpm}$ for $5 \mathrm{~min}$, and $0.2 \mathrm{ml}$ of the resulting supernatant was diluted with $5 \mathrm{ml}$ water. The acid-soluble RNA therein was measured at $260 \mathrm{~nm}$.

Electron microscopic observation. $0.002 \%$ FBP, YLP, ribonuclease A, cytochrome $c$ or Poly-Lys I was mixed with an equal volume of $0.1 \%$ TMV solutions in $0.01 \mathrm{M}$ phosphate buffer ( $\mathrm{pH}$ 7.0). After $1 \mathrm{~min}$ at room temperature, the mixture was placed on grids coated with carbon, and negatively stained with $0.01 \mathrm{ml}$ of $2 \%$ sodium phosphotungstate for $1 \mathrm{~min}$ at room temperature before being allowed to dry. The samples were examined with a Hitachi H-600 electron microscope.

Gel filtration of FBP, YLP and TMV mixtures by a Toyopearl HW50F column. After mixing $0.5 \mathrm{ml}$ of FBP $(40 \mu \mathrm{g})$, YLP $(40 \mu \mathrm{g})$ or Poly-Lys I $(40 \mu \mathrm{g})$ with $0.5 \mathrm{ml}$ of TMV $(100 \mu \mathrm{g})$ in $0.01 \mathrm{M}$ phosphate buffer $(\mathrm{pH} 7.0)$, the mixtures were stored at $4^{\circ} \mathrm{C}$ for $10 \mathrm{~min}$. The mixtures were then applied to a column of Toyopearl HW60F $(1.8 \times$ $34 \mathrm{~cm}$ ), which had been equilibrated with $0.01 \mathrm{M}$ Tris- $\mathrm{HCl}$ buffer containing $0.1 \mathrm{M} \mathrm{NaCl}$ at $\mathrm{pH}$ 7.4. Each substance was eluted with the same buffer at flow rate of $36 \mathrm{ml}$ per hr, and fractions of $1.5 \mathrm{ml}$ were collected. The eluate was measured at $210 \mathrm{~nm}$ for each substance. The inhibitory activity of TMV infection for FBP, YLP or Poly-Lys, and the infectivity for TMV in each fraction were assayed.

\section{RESULTS}

\section{Stability of the two inhibitors}

The two inhibitors were each soluble in distilled and deionized water, FBP was inactivated by dialysis against deionized water at $4^{\circ} \mathrm{C}$ for $20 \mathrm{hr}$, and YLP was stabilised under the same conditions. Neither inhibitor lost its inhibitory activity to TMV infection by lyophilization.

FBP seemed to be stable at pH 4 to 9 (Fig. 1) and YLP at pH 1 to 11, and both also seemed to be stable at below $60^{\circ} \mathrm{C}$ (Fig. 2). When YLP 
was stored in deionized water at $-30^{\circ} \mathrm{C}$ for one year, no decrease of the inhibition to TMV infection was observed.

Effect of various substances on the inhibition of $T M V$ or TMV-RNA infection

The effect of FBP, YLP, proteins, polyamino acids and basic amino acids on the inhibitory activity to TMV infection was

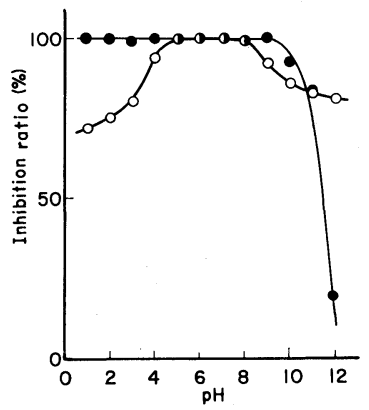

FIG. 1. pH Stability of Both Inhibitors.

$15 \mu \mathrm{g}$ of FBP or $2 \mu \mathrm{g}$ of YLP was preincubated with the buffer at the indicated $\mathrm{pH}$ for $24 \mathrm{hr}$ at $4^{\circ} \mathrm{C}$ in a total volume of $1.0 \mathrm{ml}$. The buffer used at $\mathrm{pH} 3$ to 9 was $0.05 \mathrm{M}$ veronal-acetate, and at $\mathrm{pH} 8$ to 11 was $0.05 \mathrm{M}$ borate. - - , FBP; - - - YLP. examined at the concentrations indicated in Table I.

The results shown in Table I indicate that FBP, YLP, ribonuclease A, cytochrome $c$, Poly-Lys, Poly-Orn and Poly-Arg were observed for their inhibitory activity to TMV infection, but not Poly-Leu, Poly-Ala, PolyGlu and the basic amino acids.

The effect of various concentrations of in-

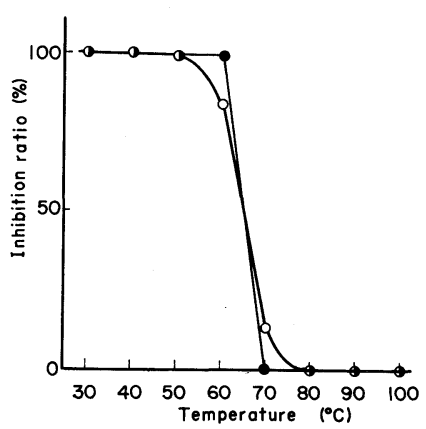

FIG. 2. Thermal Stability of Both Inhibitors.

$15 \mu \mathrm{g}$ of FBP or $2 \mu \mathrm{g}$ of YLP was heated at the indicated temperature for $10 \mathrm{~min}$ in a total volume of $1.0 \mathrm{ml}$ in $0.05 \mathrm{M}$ phosphate buffer ( $\mathrm{pH} 7.0)$, and then immediately cooled. $-\mathrm{O}-$ FBP; - - , YLP.

Table I. EFfect of Various Substances on the Inhibition of TMV Infection

\begin{tabular}{|c|c|c|c|}
\hline Substance & $\begin{array}{l}\text { Molecular } \\
\text { weight } \\
\times 10^{-3}\end{array}$ & $\begin{array}{c}\text { Concentration } \\
\text { of substance } \\
(\mathrm{ppm})\end{array}$ & $\begin{array}{c}\text { Inhibition of } \\
\text { TMV infection } \\
(\%)\end{array}$ \\
\hline FBP & 23.0 & 20 & 96 \\
\hline YLP & 23.0 & 2 & 98 \\
\hline Cytochrome $c$ & 13.7 & 200 & 95 \\
\hline Ribonuclease & 13.7 & 50 & 100 \\
\hline Lactoferrin & 77.0 & 200 & 0 \\
\hline$\alpha$-Lactoalbumin & 14.4 & 200 & 0 \\
\hline$\alpha$-Casein & 24.0 & 200 & 0 \\
\hline Poly-L-Lys I & 60.0 & 200 & 97 \\
\hline Poly-L-Lys II & 40.0 & 200 & 99 \\
\hline Poly-L-Lys III & 25.0 & 200 & 96 \\
\hline Poly-L-Lys IV & 11.0 & 200 & 80 \\
\hline Poly-L-Orn I & 110.0 & 200 & 98 \\
\hline Poly-L-Orn II & 30.0 & 200 & 98 \\
\hline Poly-L-Orn III & 10.0 & 200 & 70 \\
\hline Poly-L-Arg & 130.0 & 200 & 90 \\
\hline Poly-L-Leu & 17.0 & 200 & 0 \\
\hline Poly-L-Ala & 23.0 & 200 & 0 \\
\hline Poly-L-Glu & Unknown & 200 & 0 \\
\hline Lys & & 200 & 0 \\
\hline Orn & & 200 & 0 \\
\hline Arg & & 200 & 0 \\
\hline
\end{tabular}




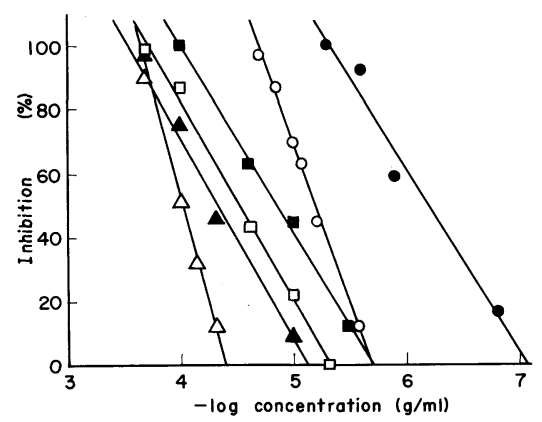

FIG. 3. Effect of Various Inhibitor Concentrations on The Inhibition of TMV Infection.

Various inhibitor concentrations in $1 \mathrm{ml}$ of $0.01 \mathrm{M}$ Tris$\mathrm{HCl}$ buffer at $\mathrm{pH} 8.0$ were used, and the assay was carried out under the conditions described in MATERIALS AND Methods. - - , YLP; — ○一, FBP; - —, Poly-Lys

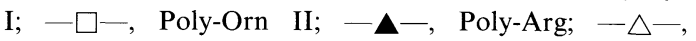
cytochrome $c$.

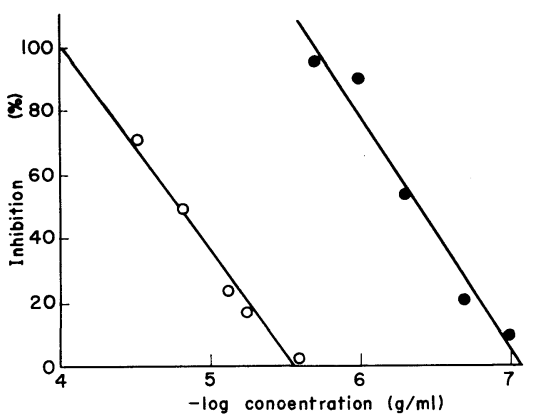

FIG. 4. Effect of FBP and YLP Concentrations on the Inhibition of TMV-RNA Infection.

The assays conditions are described in Fig. 3. - YLP; -O-, FBP.

hibitory substances against TMV infection are shown in Fig. 3. The $50 \%$ inhibition concentration against TMV infection were measured for YLP, FBP, Poly-Lys I, Poly-Orn II, Poly-Arg and cytocherome $c$ as $0.6,6.3,14.1$, 31.6, 44.7 and $100 \mathrm{ppm}$, respectively.

Effects of FBP and YLP on the inhibitory activity of TMV-ribonucleic acid infection were examined at various concentrations as shown in Fig. 4. The concentrations of YLP and $\mathrm{FBP}$ for $50 \%$ inhibition concentration were measured as 0.4 and $16.3 \mathrm{ppm}$, respectively.

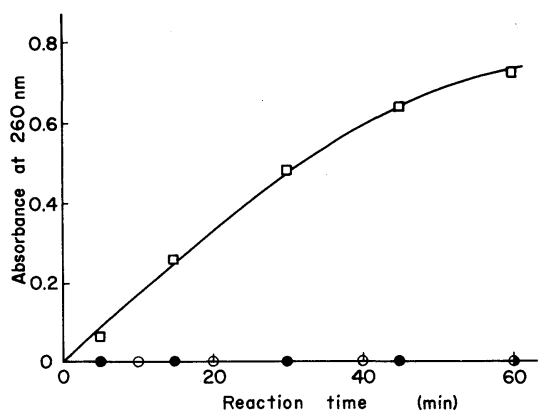

FIG. 5. Time Courses of Ribonucleic Acid Hydrolyzing Activity for FBP, YLP and RNase.

were assayed under the conditions described in MATERIALS AND Methods. - - - FBP; - - - YLP; - $\square-$, RNase.

These results suggest that the inhibition did not take place in the process of uncoating the virus, and therefore the $50 \%$ inhibition concentration of TMV did not show a significant difference from that of TMV-RNA.

RNA hydrolyzing activity of the two inhibitors

One hundred $\mu \mathrm{g}$ of FBP or VLP were assayed for RNA hydrolyzing activity under the conditions described in Materials AND Methods (Fig. 5), using $20 \mu \mathrm{g}$ of RNase to serve as a reference.

As shown in Fig. 5, neither inhibitor had activity for RNA hydrolysis.

Electron microscopy of TMV assembled in the absence or presence of FBP, YLP, RNase, cytochrome c, or Poly-Lys I

Samples containing FBP, YLP, RNase, cytochrome $c$, or Poly-Lys I in a TMV solution were examined under an electron microscope as described in MATERIALS AND METHODS (Fig. 6). It seems that the TMV particles were not effected by mixing FBP, YLP, RNase or cytochrome $c$ (Fig. 6b, c, d, and e), respectively, but were by Poly-Lys I (Fig. 6f). Thus, it is suggested that FBP, YLP, RNase, and cytochrome $c$ have no activity to aggregate TMV. On the other hand, perfect aggregation in the sample mixed with Poly-Lys I was observed. 


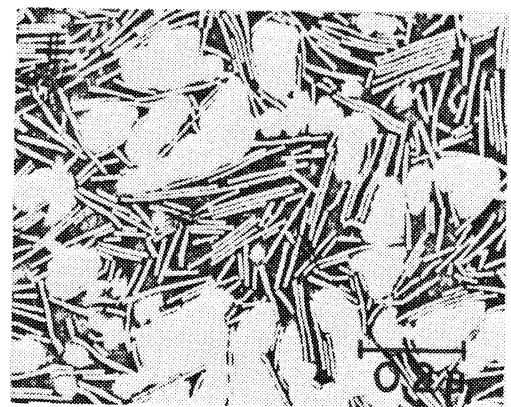

(a)

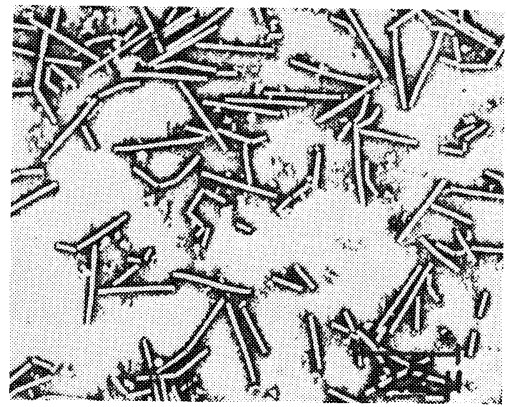

(b)

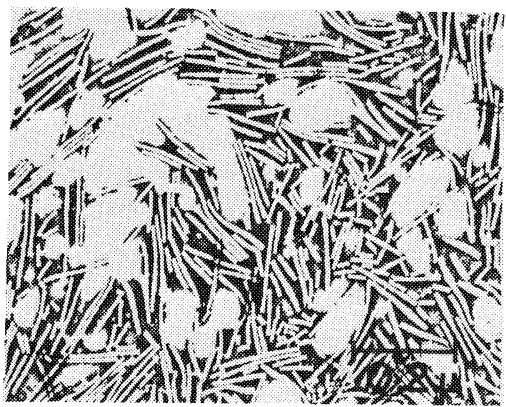

(c)

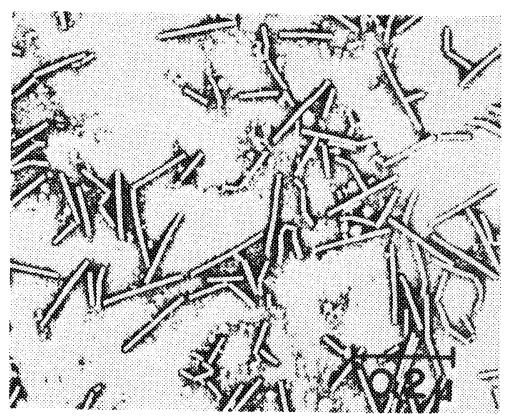

(d)

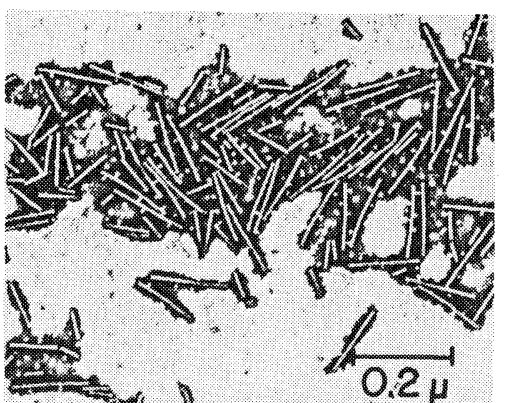

(e)

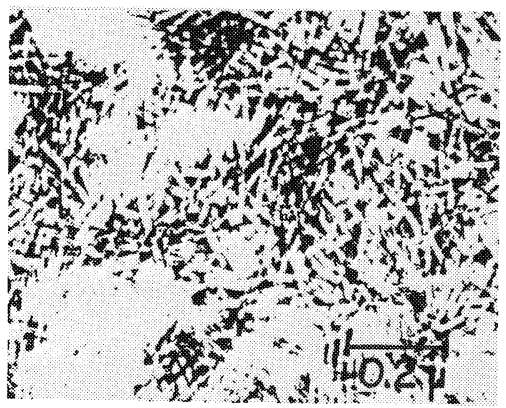

( $f$ )

FIG. 6. Electron Microscopy of TMV Assembled in the Absence or Presence of Various Inhibitors.

The samples were examined under the conditions described in Materials AND Methods. (a) TMV; (b) FBP + TMV (1:50); (c) YLP + TMV (1:50); (d) ribonuclease A + TMV (1:50); (e) cytochrome $c+$ TMV (1:50); (f) Poly-Lys I+TMV (1:50).

Gel filtration of FBP, YLP or Poly-Lys $I$ and TMV mixture

The mixtures, which contained FBP $(40 \mu \mathrm{g})$, YLP $(40 \mu \mathrm{g})$ or Poly-Lys I $(40 \mu \mathrm{g})$ and TMV $(100 \mu \mathrm{g})$, were stored at $4^{\circ} \mathrm{C}$ for $10 \mathrm{~min}$. Each mixture was chromatographed under the conditions described in MATERIALS AND METHODS. In the chromatographies (Fig. 7a and b), the mixtures were separated into FBP (II in Fig. 7a) or YLP (III in Fig. 7b) and TMV (I) fractions, respectively. The FBP and YLP fractions obtained showed the same inhibitory activity to TMV infection as the native FBP or YLP, respectively. The TMV fraction also had the same infectivity as the native one.

In the chromatography (Fig. 7c), the mix- 
TABLE II. INHIBITION OF TMV INFECTION BY BOTH INHIBITORS BEFORE AND AFTER INOCULATION

Concentration of inhibitors used the test was $15 \mu \mathrm{g}$ for FBP or $2 \mu \mathrm{g}$ for YLP in $1 \mathrm{ml}$ of $0.01 \mathrm{M}$ Tris $-\mathrm{HCl}$ buffer, $\mathrm{pH} 8.0$, respectively.

\begin{tabular}{|c|c|c|c|c|c|c|}
\hline $\begin{array}{l}\text { Time of application } \\
\text { before or after } \\
\text { inoculation }\end{array}$ & Control & $\begin{array}{c}\text { FBP } \\
\text { treated }\end{array}$ & $\begin{array}{c}\text { Inhibition of } \\
\text { TMV infection } \\
(\%)\end{array}$ & Control & $\begin{array}{c}\text { YLP } \\
\text { treated }\end{array}$ & $\begin{array}{c}\text { Inhibition of } \\
\text { TMV infection } \\
(\%)\end{array}$ \\
\hline \multicolumn{7}{|l|}{ (Before) } \\
\hline 3 days & 381 & 145 & 62 & 356 & 121 & 66 \\
\hline 1 day & 316 & 19 & 94 & 328 & 16 & 95 \\
\hline $6 \mathrm{hr}$ & 315 & 6 & 98 & 351 & 3 & 99 \\
\hline $3 \mathrm{hr}$ & 328 & 3 & 99 & 348 & 7 & 98 \\
\hline $1 \mathrm{hr}$ & 317 & 3 & 99 & 319 & 3 & 99 \\
\hline \multicolumn{7}{|l|}{ (After) } \\
\hline $1 \mathrm{hr}$ & 309 & 267 & 14 & 359 & 219 & 39 \\
\hline $3 \mathrm{hr}$ & 320 & 317 & 1 & 342 & 304 & 11 \\
\hline $6 \mathrm{hr}$ & 323 & 325 & 0 & 325 & 328 & 0 \\
\hline
\end{tabular}

a Average number of lesions per half-leaf.

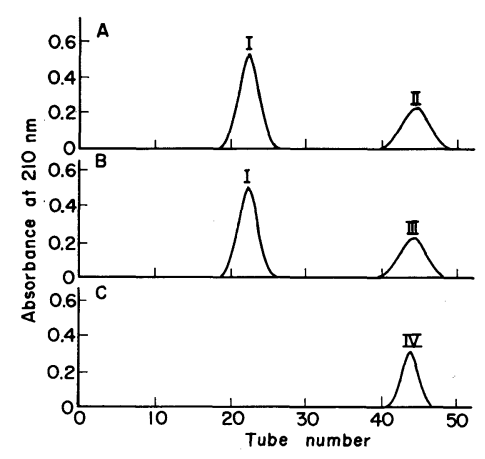

FIG. 7. Chromatography of Mixtures of FBP (a), YLP (b) and Poly-Lys I (c) with TMV on a Toyopearl HW60F Column.

The mixtures, which consisted of FBP $(40 \mu \mathrm{g})$, YLP $(40 \mu \mathrm{g})$ or Poly-Lys I $(40 \mu \mathrm{g})$ with TMV $(100 \mu \mathrm{g})$ were stored at $4^{\circ} \mathrm{C}$ for $24 \mathrm{hr}$, and then chromatographed under the conditions described in MATERIALS AND Methods. I, TMV; II, FBP; III, YLP; IV, Poly-Lys I.

ture was not separated, and only the Poly-Lys I (IV in Fig. 7c) fraction was eluted. This result suggests that not all the aggregated TMV was eluted from the top of column.

Inhibition of $T M V$ infection by FBP or YLP before inoculation

Before TMV inoculated in the leaves of the test plants, one half of the leaf was treated with FBP or YLP at various times by the method described in Materials and Methods. As a control, each other half-leaf was treated with $0.01 \mathrm{M}$ Tris- $\mathrm{HCl}$ buffer at $\mathrm{pH}$ 8.0. As shown in Table II, the leaf infection by TMV was strongly inhibited during the test period when treated with FBP or YLP.

\section{Inhibition of TMV infection by FBP or YLP after inoculation}

The leaves of the test plants were inoculated with TMV and then thoroughly washed with deionized water. After removing the water from the surface of the leaves with filter paper, one half of the leaf was treated with FBP or YLP at different intervals after inoculation by the methods described in MATERIALS AND Methods. As a control, each other half-leaf was treated with $0.01 \mathrm{~m}$ Tris- $\mathrm{HCl}$ buffer at $\mathrm{pH}$ 8.0. As shown in Table II, the infection of the test plant by TMV was slightly inhibited by treating with FBP within $1 \mathrm{hr}$ after TMV inoculation, or by YLP within $3 \mathrm{hr}$ after inoculation. No effect was observed at $6 \mathrm{hr}$ or more after inoculation.

It seems that both inhibitors had a preventive effect for plant virus infection, but no curative effect.

\section{DISCUSSION}

Okuyama reported ${ }^{14)}$ that the inhibitory 
substance in leaf juice from Yucca recurvifolia was stable at various conditions such as $\mathrm{pH} 1$ to 10 at $10^{\circ} \mathrm{C}$ for $48 \mathrm{hr}$, at $60^{\circ} \mathrm{C}$ for $10 \mathrm{~min}$, and also during dialysis against distilled water. Furthermore, it could be stored for 200 days at $10^{\circ} \mathrm{C}$ without loss of activity.

Both inhibitors also seemed to be stable at high temperatures, at various $\mathrm{pH}$ levels, and during dialysis, except for FBP which was inactivated by dialysis against deionized water. Thus, the stability of FBP during dialysis seems to require presence of metal ions or other substances.

Previously, we have reported that two inhibitors of plant virus infection were basic and consisted of simple proteins. ${ }^{1,2)}$ Cytochrome $c$, ribonuclease $\mathrm{A}$ and lactoferrin are also basic proteins. Among these, FBP and other proteins except for lactoferrin had strong inhibitory activity against TMV infection (Table I).

Skim milk $(2 \mathrm{mg} / \mathrm{ml})$ also inhibited plant virus infection to same level with Lentemin and KR-070. Lentemin was obtained from culture cells of Lentinus edodes, and KR-070 from a filtered culture of Aspergillus oryzae in a field test using pimento as a test plant. ${ }^{15)}$ However, $\alpha$-lactoalbumin and $\alpha$-casein, which are the principal ingredients of skim milk, showed no inhibition to TMV infection (Table I). Since the experimental methods and test plants used were different, we were not able to make a comparison of the $50 \%$ inhibition concentration between the inhibitors listed in Table III of a previous paper and the current two inhibitors in this paper.

It is common knowledge that Poly-Lys, which has inhibitory activity to plant virus infection, aggregates TMV. It seems that the mode of action of the two inhibitors differed, from that of Poly-Lys. ${ }^{16)}$

Mozanon, the only antiviral pesticide reported by Kubo and Tomaru, ${ }^{17)}$ a polysaccharide from marine plants which consisted principally of alginic acid polymer, and Lentemin, reported by Maeda, ${ }^{7)}$ have shown the ability to aggregate TMV. Thus, it is suggested that one mode of action of these substances is inactivation of the virus due to the aggregation of TMV.

Neither inhibitor had RNA hydrolyzing activity (Fig. 5), but both seemed to have a preventive effect, without a curative effect (Table II). It was reported by Taniguchi ${ }^{18)}$ that an extract from seems of Dianthus barbatus had no curative effect against TMV infection.

The mode of action of the two inhibitors will be discussed more in detail in subsequent papers.

Acknowledgments. Authors are indebted to Professor T. Akatsuka of Ibaraki University, to Dr. K. Shohara of the Institute of Japan Plant Protection Association for his kind guidance and instruction in the procedure for the electron microscope, to Dr. F. Sakai and Dr. Y. Otsuki of the National Institute of Agrobiological Resource for their kindly advice, to Dr. T. Nagatani of the Naka Warks of Hitachi Ltd. for his kindly help with the electron microscope, and to Mr. N. Yasunishi, Mr. G. Kozima and Mrs. H. Ishizawa for their technical cooperation.

This work supported in part by a Grant-in-Aid for Scientific Research from the Ministry of Education, Science and Culture of Japan.

\section{REFERENCES}

1) N. Kobayashi, A. Hiramatsu and T. Akatsuka, Agric. Biol. Chem., 51, 883 (1987).

2) N. Osawa and A. Hiramatsu, Agric. Biol. Chem., 51, 891 (1987).

3) F. Stirpe, D. G. Williams, L. J. Onyon, R. F. Legg and W. A. Stevens, Biochem. J., 195, 399 (1981).

4) J. D. Irvin, Arch. Biochem. Biophys., 169, 522 (1975).

5) J. D. Irvin, T. Kelly and J. D. Robertsu, Arch. Biochem. Biophys., 200, 418 (1980).

6) L. Barbieri, G. M. Aron, J. D. Irvin and F. Stirps, Biochem. J., 203, 55 (1982).

7) H. Maeda, Abstracts of Papers, Symposium on Plant Virus Inhibitors of the Japan Plant Protection Association, Tokyo, November, 1981, p. 5 (in Japanese).

8) S. Ikeda, Abstracts of Papers, Symposium on Plant Virus Inhibitors of the Japan Plant Protection Association, Tokyo, November, 1981, p. 9 (in Japanese).

9) S. Kubo, T. Ikeda, Y. Takanami and Y. Mikami, Japan Patent, S60-243100 (1085) [C.A., 105, 37465t (1985)].

10) T. Fukuchi, E. Shikata and I. Kimura, Virology, 18, 192 (1962).

11) H. Fraenkel-Conrat, B. Singer and A. Tsugita, Virology, 14, 54 (1961). 
12) S. Gianinazzi and B. Kassanis, J. Gen. Virol., 23, 1 (1974).

13) O. H. Lowry, N. J. Rosebrough, A. L. Farr and R. J. Randall, J. Biol. Chem., 193, 265 (1951).

14) S. Okuyama, K. Takemi and H. Saka, Sic. Rep. Fac. Agr. Ibaraki Univ., 26, 49 (1978) (in Japanese).

15) Y. Nagai, Abstracts of Papers, Symposium on Plant Virus Infection of the Japan Plant Protection
Association, Miyazaki, April, 1984, p. 15 (in Japanese).

16) W. C. Burger and M. A. Stahman, J. Biol. Chem., 193, 13 (1951).

17) S. Kubo and K. Tomaru, Ann. Phytophath. Soc. Jpn., 36, 231 (1973) (in Japanese).

18) T. Taniguchi, Ann. Phytophath. Soc. Jpn., 46, 628 (1980). 